Biografistyka Pedagogiczna

Rok 1 (2016) nr 1

ISSN 2543-6112; e-ISSN 2543-7399

DOI: 10.36578/BP.2016.01.12

Marek Robert Górniak*

\title{
Kształtowanie się powojennych społeczności regionalnych na Ziemiach Odzyskanych w świetle pamiętników, relacji i wspomnień osadników $\mathrm{z}$ terenu Ziemi Głogowskiej
}

\author{
Shaping Post-war Regional Communities in the Recovered \\ Territories in the Light of Diaries, Accounts and Memoirs \\ of Settlers from the Area of Ziemia Głogowska
}

\begin{abstract}
This paper presents a collection of diaries, accounts and memoirs published from 2006 to 2015 as a series of publications showing the post-war history of Lower Silesia, and Ziemia Głogowska in particular. The events of 1945 were the starting point for describing the lives of those who settled in the Recovered Territories. When comparing the fates of these people, the author also takes account of their experiences of World War II.

The Poles who settled in the Recovered Territories and Ziemia Głogowska after 1945 had different fates and experiences. Among the settlers were expatriates, people driven out of the eastern lands, those deported during the war by Soviet authorities and those displaced from central Poland. They had diverse social backgrounds and various professions.

All accounts discussed in this paper are unique and have exceptional qualities. They contain a lot of valuable information, showing different ways by which people of this region headed for their new 'little homeland'. In addition, these memories are an invaluable source of description of everyday life, mental attitudes and the process in which the Poles were rooted in these lands. They also make it possible to reconstruct local particularities and the social climate of the post-war years.
\end{abstract}

* Marek Robert Górniak - mgr, pracownik Biblioteki Uniwersyteckiej Katolickiego Uniwersytetu Lubelskiego Jana Pawła II, mrgglogau@wp.pl. 
In the years 1945-1950, the population in Ziemia Głogowska was not uniform in ethno-cultural terms and the integration process was slow. Creating new social ties took place in three stages. The initial stage of the colonization of the Recovered Territories was characterized by separatism resulting from differences in the regional origins of settlers (including various traditions and visions of the functioning of the community). The second stage of integration and adaptation (until 1958) was characterized by a gradual loss of cultural differences, the penetration of diverse regional cultures and the emergence of a sense of attachment to these lands. In the third stage (after 1958), people ceased to doubt that these lands belonged to Poland only temporarily and made this area similar to the rest of the country.

The post-war memoirs give a multifaceted picture of the post-war reality, thus contributing significantly to the achievements of post-war Polish historiography concerning Ziemia Głogowska, and more broadly, the Recovered Territories.

Keywords: Ziemia Głogowska, Recovered Territories, diaries, accounts, memoirs, resettlement

\section{Rozważania wstępne}

Wielokulturowość na Ziemiach Zachodnich i Północnych jest swoista oraz niespotykana w innych częściach Polski. Nie wiąże się to z wieloetnicznością, lecz z regionalno-etnologicznymi odmiennościami. Zbigniew Mazur dowodzil, iż dla pierwszego pokolenia osadników na Ziemiach Odzyskanych pewne elementy zastanego tu dziedzictwa

1 M. R. Górniak, Ziemie Odzyskane, w: Encyklopedia „Białych Plam”, t. 18, red. A. Winiarczyk, Radom 2006, s. 252-255; J. Jasiński, Kwestia pojęcia Ziemie Odzyskane, w: Ziemie Odzyskane / Ziemie Zachodnie i Północne 1945-2005. 6o lat w granicach państwa polskiego, red. A. Sakson, Poznań 2006, s. 27-44; H. Mordawski, Ziemie Odzyskane 1945-1956, Brzezia Łąka 2015, s. 11-12. Termin „Ziemie Odzyskane” odnoszony jest do obszaru położonego na wschód od Odry i Nysy Łużyckiej, o powierzchni 103788 km² (w 1939 r. mieszkało tu 8800000 osób). Przyznane zostały one Polsce na mocy uchwał konferencji w Jałcie i Poczdamie w 1945 r. Wprowadzona do obiegu nazwa „Ziemie Odzyskane”, choć nie była terminem historycznie ścisłym, okazała się udanym zabiegiem socjotechnicznym. Janusz Jasiński w swojej pracy m.in. dowodził, iż określenie to było w latach 1945-1948 nazwą oficjalną, a zatem zgodnie z dotychczasowymi zwyczajami historiografii polskiej nie powinniśmy dystansować się od niej. Dalej wnioskował, że nazwa ta jest swego rodzaju syntezą politycznej myśli zachodniej Polaków, a jeżeli podważamy sensowność tego terminu, tym samym zakładamy, że były to ziemie niepolskie, ergo niemieckie. 
lokalnego nie były w ogóle możliwe do przyswojenia. Natomiast dla kolejnych pokoleń, nieobciążonych już balastem obcości tych ziem (w tym krajobrazu naturalnego i kulturowego), pewną trudnością stało się przezwyciężenie alienacji historycznej i problem zakorzenienia w historii, a w konsekwencji pełne jej zrozumienie oraz zaakceptowanie faktu, że przed drugą wojną światową przeważało tu dziedzictwo niemieckie².

Powojenni osadnicy - nowi mieszkańcy - nie identyfikowali się z zastanym tu kulturalnym dziedzictwem, a „oswajanie" przez nich nowej ojczyzny oznaczało m.in. usuwanie zastanych obcych im symboli, niemieckich nazw miejscowości, ulic, obiektów i pomników. Odbywało się to zarówno drogą urzędowych nakazów, jak i oddolnie, spontanicznie, jako swoiste odreagowanie niedawno zakończonej wojny. Decyzje podejmowane przez polskie władze miały głównie na celu przystosowanie nowego otoczenia do potrzeb oraz wymagań przybyszów, mimo iż cechowała ich odmienność regionalnego pochodzenia i cywilizacyjnego poziomu. Zróżnicowanie osadników początkowo nie ułatwiało tworzenia się spójnej społeczności i prawidłowej koegzzystencji. Przybywające z różnych stron grupy mieszkańców bardzo często dążyły do wyłączności kontaktów w swoim środowiskowym i regionalnym gronie, czego dowodziło również zasiedlanie poszczególnych miejscowości (na przykład Grębocice - z Lubelszczyzny, Jaczów - z Kresów Wschodnich, Przedmoście - z Wielkopolski). Należy jednocześnie

2 Z. Mazur, O adaptacji niemieckiego dziedzictwa kulturowego na Ziemiach Zachodnich i Pótnocnych, Poznań 2001, s. 23; J. Nowosielska-Sobel, „Na barkach nieśli krajobraz” - z problemów oswajania przez osadników przestrzeni na przykładzie powiatu jeleniogórskiego drugiej połowy lat 40., w: Trudne dziedzictwo. Tradycje dawnych i obecnych mieszkańców Dolnego Śląska, red. J. Nowosielska-Sobel, G. Strauchold, Wrocław 2006, s. 108-110; J. Habranowicz, Wielokulturowość Ziem Zachodnich po II wojnie światowej w pamiętnikach osadników, „Dolny Śląsk”, 14 (2008) nr 13, s. 42; Z. Rykiel, Kolonizacja a tożsamość społeczna na Ziemiach Zachodnich - przykład Zielonej Góry, w: Polskie Ziemie Zachodnie. Studia socjologiczne, red. A. Michalak, A. Sakson, Ż. Stasieniuk, Poznań 2011, s. 101. Zbigniew Rykiel, analizując status ontologiczny Ziem Zachodnich, dowodził: „Nie ulega wątpliwości, że pojęcie «ziem odzyskanych» jest zasadne do tych terytoriów, które należały do Rzeczypospolitej przedrozbiorowej. W odniesieniu do innych ziem zasadność używania tego pojęcia jest mniej oczywista, wiąże się bowiem z kwestią sukcesji prawnej. W przypadku Śląska pojęcie odzyskania trzeba by wiązać co najmniej z okresem Polski kazimierzowskiej (XIV w.), a może nawet piastowskiej. Przypadek Pomorza Zachodniego jest jeszcze mniej oczywisty, było ono bowiem częścią państwa polskiego krótko i dawno - za panowania Mieszka I i Bolesława Krzywoustego. W przypadku natomiast większej części Prus (później zwanych Wschodnimi) trudno w ogóle mówić o odzyskaniu, ziemie te bowiem nigdy do państwa polskiego nie należały, chociaż przez dwa wieki stanowiły część lenna pruskiego Polski". 
zaznaczyć, iż w procesie wzajemnej akulturacji (szczególnie w środowiskach wiejskich i małomiasteczkowych) oraz w dostosowaniu do nowych warunków poza lokalnymi władzami ogromną rolę odegrał Kościół katolicki, szkoła oraz organizacje społeczne (takie jak choćby ochotnicze straże pożarne) $)^{3}$.

Ważną część nowej społeczności Ziem Odzyskanych stanowili Kresowianie, którzy mimo długo wszechobecnego poczucia tymczasowości - nadawali koloryt tym ziemiom. Przede wszystkim społeczność ta - w wyniku pojałtańskiego nowego porządku w Europie - nie miała dokąd wracać. Jednocześnie stanowili oni początkowo społeczność nieustabilizowaną. Cechowała ich niechęć do definitywnego obejmowania przydzielonych im domostw i gospodarstw oraz ciągła obawa przed powrotem niemieckich gospodarzy, z którymi niejednokrotnie wspólnie bytowali pod jednym dachem, jeszcze przed ich przymusowym wysiedleniem. U Kresowian doświadczenia z przeszłości i realna ocena narzuconego nowego ładu politycznego oraz konflikty o podłożu regionalnym dodatkowo wzmacniały poczucie tymczasowości i marzenia o powrocie w strony rodzinne. Ciężko przeżywali oni zarówno rozstanie ze swoją ojcowizną na wschodzie, jak i asymilację w nowej, nieznanej im oraz obcej rzeczywistości. Wszystko wokół było dla nich inne - krajobraz, klimat czy infrastruktura. Dlatego nie ulega wątpliwości, że dwa pierwsze pokolenia wywodzące się z Kresów zakorzeniały się w nowym miejscu wyjątkowo opornie ${ }^{4}$. Kazimierz Laba, mieszkaniec Przedmościa, pochodzący z rejonu kałuskiego w województwie stanisławowskim, z nostalgią wspominał:

3 T. Kulak, Wrocław - polskie miasto o niemieckiej przeszłości, w: Poznań - Szczecin - Wrocław. Trzy uniwersytety, trzy miasta, trzy regiony, red. W. Łazuga, S. Paczos, Poznań 2010, s. 90-91; W. Jacher, Problemy adaptacji społeczno-kulturowej ludności polskiej na Ziemiach Zachodnich i Pótnocnych po 1945 roku, w: Polskie Ziemie Zachodnie. Studia socjologiczne, Poznań 2011, s. 74; P. Szulc, Pozyskane ziemie odzyskane, „Pamięć i Przeszłość”, 15 (2015) nr 2(28), s. 6-14; R. Żurek, Kościót rzymskokatolicki w Polsce wobec Ziem Zachodnich i Północnych 1945-1948, Szczecin-Warszawa-Wrocław 2015, s. 470-509; M. R. Górniak, 70 lat Ochotniczej Straży Pożarnej w Jaczowie. Zarys dziejów 1946-2016, Jerzmanowa-Lublin 2016, s. 25-38.

4 A. Sakson, Procesy integracji i dezintegracji społecznej na Ziemiach Zachodnich i Pótnocnych Polski po 1945 roku, w: Pomorze - trudna ojczyzna. Kształtowanie się nowej tożsamości 1945-1995, red. A. Sakson, Poznań 1996, s. 139; A. Hanich, Powojenna „repatriacja” Polaków $z$ Kresów Wschodnich na Ślassk Opolski, w: Wokół ludzi i zdarzeń. Przesiedleńcy z dawnych Kresów Rzeczypospolitej w strukturze demograficznej i społecznej Śląska Opolskiego w sześćdziesięcioleciu 1945-2005, Opole 2011, s. 21-22; W. Suleja, Trudny proces zakorzeniania. Kresowiacy na Dolnym Śląsku, w: Kresowe dziedzictwo. Studia nad językiem, historią i kultura, red. A. Budzyńska-Kamieniecka, M. Misiak, J. Kamieniecki, Wrocław 2012, s. 269-275. 
Mamę pochowaliśmy na cmentarzu w Przedmościu [obecnie gmina Głogów przyp. M.R.G.], a ojciec niestety został w rejonie stanisławowskim. A takie ziemie tam dobre były, i co? Gospodarki popalili, poniszczyli i nikomu ani grosza, nic a nic, za to nie zapłacili. Po przyjeździe [na Ziemię Głogowską] drugi raz trzeba nam było rękawy zakasać i wszystko od nowa zrobić.

Z kolei Janina Zimińska, pochodząca z okolic Łucka w okręgu wołyńskim, jako sześcioletnia dziewczynka zapamiętała pierwsze tygodnie na Ziemi Głogowskiej po przybyciu do Wilczyna (gmina Grębocice):

Pamiętam pierwsze wejście do „naszego" domu. Ładny, drewniany ganek, z niego podwójne, z kolorowymi szybkami, drzwi do sieni. Z podobnymi szybkami drzwi do innych pomieszczeń, a wszędzie szkło, gruz i słoma. „To tylko na razie - mówił ojciec -za parę dni będzie znowu wojna, i pojedziemy za Bug, do naszego Głęboczka". Jednak mijały dni, a wojny nie było. Trzeba było jakoś żyć, coś jeść, uprawiać. Pewnego, ciepłego dnia rodzice postanowili uprawić kawałeczek ziemi za domem. Spalono zgromadzone na kilka stosów śmiecie. Potem ojciec wynalazł jakiś stary, drewniany pług, a że nikt we wsi jeszcze nie miał konia, to pług ciągnęły mama i ciocia.

Jak trafnie zauważyła Ewa Czaińska, wprowadzenie po wojnie w Polsce centralnie kierowanej gospodarki spowodowało zablokowanie wyjątkowo cennej oddolnej inicjatywy stwarzającej szansę nawiązania nowych więzi społecznych związanych z zagospodarowaniem tego rejonu. W konsekwencji zahamowano proces tworzenia świadomości tożsamości lokalnej i odpowiedzialności za te ziemie, a nawet spotęgowano poczucie tymczasowości ${ }^{7}$ Ewidentnym przykładem braku przywiązania emocjonalnego do nowej ojczyzny była sytuacja najważniejszej miejscowości Ziemi GłogowskiejGłogowa. Jeszcze do połowy lat pięćdziesiątych XX w. nie udało się tu uporządkować zrujnowanego podczas działań wojennych „miasta gruzów”. Doprowadzono do porządku jedynie drogi przelotowe i ulice w pobliżu zasiedlonych domostw. Prasa regionalna, zamieszczając informacje o Głogowie pierwszej powojennej dekady, donosiła:

5 K. Frąszczak, M. R. Górniak, M. Kuchnicki, Pamiętniki, relacje i wspomnienia osadników obecnej gminy Głogów (część 1). Przedmoście, Głogów-Lublin 2015, s. 147-148.

6 M. R. Górniak, Pamiętniki i wspomnienia osadników rejonu gminy Grębocice (zeszyt 2). Powojenne relacje nauczycieli i absolwentów szkół z terenu gminy, Grębocice-Lublin 2008, s. 90.

7 J. Chutkowski, Głogów w XX wieku. Zarys monograficzny, Głogów 2004, s. 125-127; E. Czainska, Świadomość tożsamości lokalnej a jej wpływ na rozwój gospodarczy miasta Głogowa, w: Głogów tu i teraz, red. E. Czaińska, J. Hermaszewski, B. Kohlman, Głogów 2011, s. 89-90. 
[...] ulice nie są ani zbyt czyste, ani też zabezpieczone. Dziury w chodnikach narażają przechodniów w najlepszym razie na potłuczenie. Aleja Wolności [centralna ulica miasta - przyp. M.R.G.] jest nieoświetlona ${ }^{8}$.

W 1951 r. powstał w Głogowie Powiatowy Oddział Robót Rozbiórkowych i rozpoczęły się trwające do lat sześćdziesiątych prace nad odgruzowaniem miasta. Co ciekawe, oczyszczoną cegłę z rozebranych ruin, a niekiedy z nadających się jeszcze do odbudowy domów, odtransportowano do Warszawy lub innych odbudowywanych miast ${ }^{9}$. Opis dotyczący tej skomplikowanej sytuacji w powojennym Głogowie odnajdujemy m.in. w relacji Rozalii Berhel:

Nigdy nie zapomnę widoku Głogowa po wojnie. Była to jedna wielka ruina. Stało zaledwie kilka kamienic. Nie były one całkiem zniszczone, więc ludzie mogliby w nich zamieszkać po zrobieniu dachu i wstawieniu okien, niestety wszystkie zostały zburzone a cegły wysłane do Warszawy na budowę lotniska. Wykopano też kostkę brukową i ją także wysłano. Dużo spalono i poniszczono. Obok kolegiaty głogowskiej stał hotel, w nim urządzono restaurację. Widzieliśmy tam kufle na piwo, stoliki i krzesła, a u góry w hotelu pierzyny i poduszki. Kiedy wróciliśmy na drugi dzień, aby wziąć sobie coś do domów wszystko już się paliło. Było nam przykro, bo niczego nie mieliśmy, a tak się zmarnowało. Mówiono, że to Ruscy tak niszczyli, ale do końca nie wiadomo, czy nie były to jakieś bandy. Na ulicach leżało pełno trupów i rozchodził się okropny smród. Pionierzy, którzy zasiedlili Głogów, musieli to wszystko sprzątać, a my im pomagaliśmy. Najwięcej ciał leżało w rowach $[. . .]^{10}$.

Mimo rozlicznych utrudnień z czasem zaszczepione u osadników przekonanie o wspólnocie pochodzenia i wspólnych wartościach narodowych stało się niewątpliwie czynnikiem wspierającym integrację oraz zharmonizowania wzorów społecznych. Migracja oraz konieczność zamieszkania w nowym otoczeniu zbiegły się w czasie z restruktury-

8 J. Chutkowski, Głogów w Xx wieku, s. 125-127; E. Czaińska, Charakterystyka uwarunkowań kształtowania się osadnictwa oraz rozwoju miasta Głogowa pod wpływem powstania Huty Miedzi, w: Głogów historia i perspektywy rozwoju, red. J. Hermaszewski, E. Czaińska, B. Kohlman, Głogów 2010, s. 95-96.

9 B. Nitschke, Oswajanie „małych ojczyzn” na przykładzie odbudowy Starego Miasta Głogowie, w: Głogów. Historia i perspektywy rozwoju, red. J. Hermaszewski, E. Czaińska, B. Kohlman, Głogów 2010, s. 46-49.

10 J. Baraniecki, M. R. Górniak, Relacje i wspomnienia osadników rejonu gminy Kotla, KotlaLublin 2012, s. 55-66; H. Wojtowicz, M. Garbera, Rozalia Berhel, w: Ocaleni z zatraty II. Relacje mieszkańców ziemi lubińsko-legnickiej, red. A. Bereś, Wrocław 2014, s. 88. 
zacją porządku społecznego (o charakterze rewolucji społecznej). Osadnicy, którzy przybyli tu w większych grupach, trzymali się razem i wspierali. Współuczestnictwo w życiu społecznym z czasem zatarło pojęcia „obcy" $i$ „swój”, doprowadzając do powolnego kształtowania się poczucia przynależności lokalnej. Bezpośredni kontakt z cywilizacyjnymi dokonaniami Niemców (m.in. maszyny rolnicze, melioracje, wodociąi i linie elektroenergetyczne) ułatwił przybyszom przezwyciężenie poczucia utraty ojczyzny i zaakceptowanie nowych warunków życia. Dowody otwarcia się na innych oraz pomyślności adaptacji dostarczały przykłady życia codziennego (m.in. wymieniano się przepisami kulinarnymi, peklowanie mięsa i suszenie owoców częściej zastępowano wekowaniem, a drewniane naczynia kuchenne wymieniono na emaliowane) ${ }^{11}$.

\section{Sytuacja społeczno-polityczna na Ziemi Głogowskiej po zakończeniu działań wojennych}

W następstwie działań wojennych (trwającego niemal 7 tygodni oblężenia) miasto faktycznie przestało istnieć i stanowiło ogromne, dopalające się rumowisko. Większość ulic i placów była poprzecinana rowami i pokryta pociskami. Pierwsze zetknięcie z powojenną rzeczywistością i wrażenia przybywających tu osadników były dla nich szokiem ${ }^{12}$.

11 K. Kwaśniewski, Adaptacja i integracja kulturowa ludności Śląska po II wojnie światowej, Wrocław 1968, s. 13-15; P. Lewandowski, Wschód i zachód przemieszczone oraz odtworzone. Powstanie postmigracyjnego społeczeństwa polskich Ziem Zachodnich, „Kultura i Społeczeństwo”, 2013 nr 3, s. 209-210; B. Halicka, Polski Dziki Zachód. Przymusowe migracje i kulturowe oswajanie Nadodrza 1945-1948, Kraków 2015, s. 368. Autorka, podejmując zagadnienie dokonującej się po wojnie rewolucji społecznej w rozdziale niniejszej monografii zatytułowanym Nowe społeczeństwo - mieszanka kulturowa i etniczna, słusznie zauważyła: „ci, którzy w rodzinnych stronach uchodzili za bogatych czy biednych, zostali postawieni na równi. Bezrolnych chłopów i robotników rolnych nie było już praktycznie wcale, pomagano więc sobie nawzajem i wymieniano się narzędziami rolniczymi. Wyznacznikiem pozycji społecznej były odniesione sukcesy bądź funkcje pełnione w ramach danej grupy".

12 J. Chutkowski, Głogów w XX wieku, s. 71-72; K. Matwijowski, Głogów. Zarys monografii miasta, Wrocław 1994, s. 230-231; W. Maciuszczak, Twierdza Głogów. Garnizon i ludzie. 16302009, Głogów 2009 (passim); M. Konopnicka, J. Helwig, Wstęp do dziennika Paula Pätzolda, w: Glogau 1945. Upadek twierdzy, Wrocław-Głogów 2015, s. 109-147. Zacięte walki o miasto, przy użyciu znacznej ilości artylerii i lotnictwa, toczyły się od 9 lutego do 31 marca 1945 r.. Oblężenie przeżyło tylko ok. 1000 osób. 
Wspomnienia świadków jednoznacznie wskazywały, że skala zniszczeń Głogowa była duża, a miasto nie nadawało się do normalnej egzzystencji. Ta sytuacja wręcz paraliżowała przyjezdnych i budziła wiele wątpliwości. Jedna z osadniczek - Michalina Hankiewicz pochodząca z okolic Kałusza w województwie stanisławowskim opisała swoje wrażenia w następujący sposób:

Gdy nasz pociąg zatrzymał się, wyszłam na moment z wagonu na stację kolejową. Dworzec w Głogowie był spalony, wszystko dookoła poprzewracane i zniszczone. Niesprawne wagony i różnorodne rzeczy. Całość przedstawiała okropny widok. W gruzach natknęłam się na trupy niepogrzebanych Niemców. Wróciłam do wagonu. Po chwili pociąg udał się dalej. Na bocznicy towarowej nie było wcale lepiej, ale tam już kazano nam się wyładować. Jednak nikt dobrowolnie z wagonu nie chciał wychodzić. Wtedy przyszedł oficer radziecki i rozkazał natychmiast wagon odczepić. W ten sposób pozostawiono nas między gruzami i dymiącymi jeszcze zgliszczami Głogowa ${ }^{13}$.

Mimo iż nakazano nam wzmożoną ostrożność, wyjątkowo trudno było utrzymać małe dzieci, aby nie ryzykowały chodzenia wśród gruzów. Gdy pewnego dnia jeden z chłopców wyszedł z domu bez opieki starszej osoby, doszło do tragedii. Nieświadom niebezpieczeństwa oddalił się i wszedł na minę. W wyniku wybuchu zginął na miejscu. Po tym strasznym wypadku część naszych rodzin zwątpiła w sens pozostawania w zaminowanym mieście i namawiano nas do opuszczenia Głogowa. Dlatego poszliśmy szukać zakwaterowania w najbliżej okolicy ${ }^{14}$.

Kapitulacja hitlerowskich Niemiec i koniec działań wojennych przyniosły nowe granice i Ziemia Głogowska znalazła się ponownie w obrębie Polski. W chwili przejmowania tego terenu przez Polaków nastąpiła wielka „wędrówka narodów”, wszystko było płynne, wszyscy wędrowali. W tym zamieszaniu odbywała się wymiana ludności niemieckiej na polską. Wspólne losy połączyły ich na dolę i niedolę $e^{15}$ Skomplikowaną sytuację, chaos organizacyjny i warunki, w których nastąpiło zetknięcie się pierwszych

13 M. R. Górniak, Pamiętniki, relacje i wspomnienia osadników rejonu obecnej gminy Jerzmanowa (część 2). Robotnicy przymusowi, pionierzy polskiego osadnictwa i ich następcy, Jerzmanowa-Lublin 2014, s. 51.

14 Tamże, s. 53.

15 B. Kominek, W służbie „Ziem Zachodnich”, Wrocław 1977, s. 37-42; M. R. Górniak, Społeczno-religijna rola zakonów i stowarzyszeń katolickich w powojennych dziejach Ziemi Głogowskiej (ze szczególnym uwzględnieniem okresu pionierskiego 1945-1960), w: Głogów tu i teraz, red. E. Czaińska, J. Hermaszewski, B. Kohlman, Głogów 2011, s. 98. 
grup przesiedleńczych z nowym miejscem, ukazywał m.in. raport inspektora osadnictwa w Głogowie z 10 czerwca 1945 r:

Na stacji kolejowej Niederfeld [Grodziec Mały - obecnie gmina Głogów; przyp. M.R.G.] pracownicy PUR zastali około 2,5 tys. repatriantów przywiezionych dwoma transportami. Repatrianci z oburzeniem zakomunikowali o całym szeregu faktów, jakie miały miejsce przy wysyłaniu ich z Poznania, podczas drogi i rozładowania. Przedstawiciele PUR w Poznaniu oświadczyli im, ludności w większości miejskiej, że zostaną skierowani do pięknego miasta Głogowa, w którym wszyscy znajdą możność osiedlenia się i uzyskania dla siebie zarobkowania. [...] Po przybyciu na miejsce przekonali się, że miasto Głogów nie istnieje i że zamiast rozlokowania ich w mieście, zmuszeni są szukać schroniska w tłoczeniu się po osiedlach wiejskich. [...] Nakazano im pod groźbą użycia broni wyładunek, podczas ciemnej nocy i deszczu wprost w bagno, zaszły [wtedy] wypadki użycia przemocy fizycznej. Wagony zostały zabrane tak szybko, że część rzeczy nie zdążono wyładować i odjechały z powrotem. [...] Repatriantom oświadczono w Poznaniu, że jadą oni na teren przygotowany do osadnictwa, tymczasem trafili w najokropniejsze warunki sanitarne i bezpieczeństwa, gdyż na teren, który z czasów długotrwałych bojów o Głogów, jako jego przedpole pokryty jest nie pochowanymi trupami żołnierzy i padliną, a także dotychczas nie został rozminowany. [...] Pomocy lekarskiej ani sanitarnej nie było, ani w transporcie, ani na miejscu, gdyż takowych brak jest w powiecie głogowskim. [...] Repatrianci zmuszeni byli rozsiedlać się w okolicy na piechotę, co przewlekało akcję ${ }^{16}$.

\section{Osadnicy w nowej rzeczywistości na Ziemiach Odzyskanych}

Powojenne wspomnienia, relacje i pamiętniki zaliczane są do najciekawszych dokumentów obrazujących bezprecedensowe zetknięcie różnych kultur, jakie nastąpiło na Dolnym Śląsku po 1945 r. Jeden z pionierów osadnictwa, rolnik Józef Boliński z podgłogowskich Grębocic, tak oto opisał swoje refleksje na temat mieszkańców tych ziem, którzy mimo ewidentnego zróżnicowania, różnych tożsamości i kultur z czasem stali się nową społecznością Ziem Zachodnich, a szerzej - integralną częścią społeczeństwa narodowego:

16 Archiwum Akt Nowych Zarząd Centralny (w Łodzi) Państwowego Urzędu Repatriacyjnego nr zespołu: 200/o, syggn. II/15, k. 40-41; M. Hejger, Przekształcenia narodowościowe na Ziemiach Zachodnich i Pótnocnych Polski w latach 1945-1959, Słupsk 2008, s. 34, M. R. Górniak, Pamiętniki i wspomnienia osadników rejonu gminy Grębocice (zeszyt 3). Pionierzy i ich następcy, Grębocice-Lublin 2011, s. 10-11. 
Fotografia 1. Ekspatrianci z Kresów Wschodnich (z województwa tarnopolskiego), którzy przybyli na Ziemię Głogowską, do miejscowości Grodziec Mały (obecnie w gminie wiejskiej Głogów), maj 1945 r.

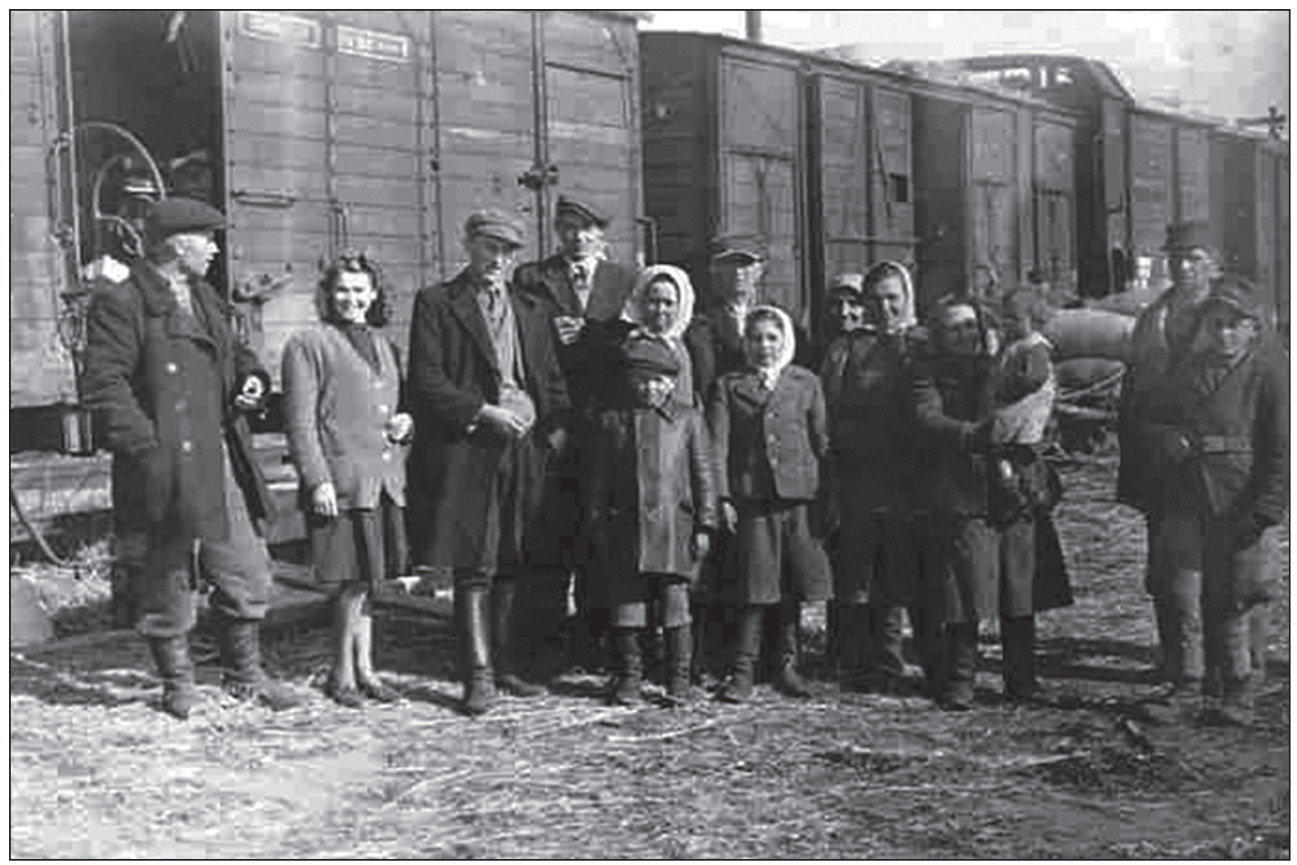

Źródło: Ze zbiorów rodzinnych Bronisławy Zapotocznej. Archiwum autora.

Mieszkańcy Grębocic pochodzili z różnych stron. Mieli odmienne tradycje i zwyczaje, jednak powoli zacierały się różnice między nimi. Ludzie żyli nad wyraz zgodnie i pomagali sobie wzajemnie. Początkowe konflikty i podziały z czasem po prostu zacierały się. O ile wcześniej najbardziej odosobnieni byli mieszkańcy którzy wywodzili się z Łemkowszczyzny, o tyle później nie dochodziło do takich „podziałów". Przykładem bardzo pozytywnie odbieranego i wzorowego mieszkańca Grębocic, który budził szacunek u wszystkich, był [Łemko] pan Damian Rotko. Wszystkich nas połączyły podobne problemy i zmagania z powojennymi losami. Ludzie wtedy na wsi wiedli monotonne życie, więc próbowali je sobie umilać. Często wtedy spotykano się na wspólnych zabawach, organizowano potańcówki (młodzież bawiła się najczęściej wieczorami na świeżym powietrzu), na których grali wiejscy muzykanci17.

Podobne refleksje z powodu rozróżniania i podkreślania różnic dzielących przybyszów z różnych regionów czy zakątków Europy (szczególnie wśród mieszkańców wsi)

17 M. R. Górniak, Pamiętniki i wspomnienia osadników rejonu gminy Grębocice (zeszyt 3), s. 50-51. 
odnajdujemy w relacji Czesławy Borwik z domu Drankiewicz. Opisując rodzinną wieś, w której dominowali głównie przybysze z Wielkopolski, skupiła się także na osadnikach przybyłych z Rumuni. Podkreślała, jak mocno odstawali oni od przesiedleńców z Polski i w jak trudnej sytuacji bytowej się znajdowali:

Po wojnie ze wszystkich stron tu ludzie zjechali. Taka różnorodność tu była. Bardzo dużo przyjechało ludzi na przykład z Niemiec, czy nawet z Belgii, tych wszystkich, co pracowali przymusowo. A z Rumuni to już przyjeżdżali w latach 5o-tych, bo pamiętam, że ja już chodziłam do szkoły, ale nie wiem do której klasy. Przyjechała m.in. rodzina państwa Curkanów. Na początku było im bardzo trudno, tym bardziej że „Rumuny” czy też „Rumuni” na nich mówili. Mieli żal o to do ludzi, bo w sumie nie wiedzieli, kim są, a na Bukowinie (bo oni z Bukowiny przyjechali) to ich przezywali „Mazury”, dlatego że są z pochodzenia Polakami. Ale nie mówili, że są Polakami, tylko Mazurami. W konsekwencji to Bukowińczycy mówili: „W końcu kim my jesteśmy?”. Po polsku mówili przecież. Bez wątpienia byli to Polacy. Przyjeżdżali stamtąd jako strasznie biedni ludzie ${ }^{18}$.

W ten sam sposób refleksje dotyczące zróżnicowania osiedlonych po wojnie mieszkańców w swoim pamiętniku odnotował nauczyciel Edward Bora obejmujący posadę kierownika Szkoły Podstawowej w Grębocicach w latach 1950-1952:

Przybyła tu ludność rekrutowała się z byłych ziem Polski Wschodniej, Poznańskiego i Polski Centralnej. Ponieważ panowała powszechna opinia, że ludzie zza Buga są gościnni, a z Poznańskiego skąpi, wytworzyła się niepisana rywalizacja: i jedni i drudzy prześcigali się w uprzejmości. $\mathrm{W}$ trzecim roku naszego pobytu w Grębocicach, w czasie żniw wracał z pola ze snopowiązałką w trzy konie sąsiadujący ze szkołą gospodarz. Wstąpił do mnie i zameldował: „Pszenicę Pana skosiłem, proszę ją zestawić w mendle"119.

Niekiedy autorzy wspomnien, poza skomplikowanymi losami i trudnościami nowo przybyłych, ich zagubieniem oraz poczuciem obcości, dostrzegali również trudną sytuację Niemców, których jako dawnych ciemiężycieli spotkał dramatyczny los i konieczność opuszczenia tych ziem. Jak dowodziła Bernadetta Nitschke, niektórzy Niemcy zmuszeni do opuszczenia rodzinnych stron stanęli w obliczu tragedii życiowej.

18 K. Frąszczak, M. R. Górniak, M. Kuchnicki, Pamiętniki, relacje i wspomnienia osadników obecnej gminy Głogów (część 1), s. 46-47.

19 M. R. Górniak, Pamiętniki i wspomnienia osadników rejonu gminy Grębocice (zeszyt 2), s. 17. 
Fizycznie zostali oderwani od znanego, bliskiego krajobrazu kulturowego ${ }^{20}$. Wacław Borwik, mieszkaniec wsi Przedmoście (który w 1946 r. przybył tu jako sześciolatek wraz z rodzicami i rodzeństwem), zapamiętał i opisał wydarzenia widziane oczyma małego dziecka:

W Przedmościu zajęliśmy [poniemieckie] gospodarstwo. Choć jeszcze, gdzieniegdzie mieszkali tu Niemcy, to tam gdzie my zamieszkaliśmy, już Niemców nie było. ... Jak dobrze pamiętam, w 1947 roku, trudno mi jednak dokładnie powiedzieć, kiedy nastąpiła deportacja Niemców. Jak pamiętam, to my się bardzo żeśmy z nimi zaprzyjaźnili. Może nie tyle nasi rodzice, ale choćby ja jako chłopiec. Dlatego jak ich wywozili, to płakałem. Teraz niestety nie pamiętam nazwisk tych Niemców. [...] Wywożono Niemców tak zwanymi podwodami, tak to się kiedyś nazywało. Muszę jednak zaznaczyć, że nie było jakiś krzyków czy popychania, a wręcz było normalnie. Mało Niemców tu pozostało w 1947 roku. Może drobne zatargi były jeszcze z niektórymi, ale my jak pamiętam, żyliśmy z nimi w przyjaźni. W naszym wieku utrzymywaliśmy z nimi stosunki wręcz koleżeńskie. No bo ile można było wiedzieći do końca rozumieć, jak się miało 7-8 lat? Dzieci po prostu się zaprzyjaźniły ${ }^{21}$.

W omawianych wspomnieniach i relacjach $\mathrm{z}$ rejonu głogowskiego można przytoczyć wiele przykładów odniesienia się do sytuacji ludności niemieckiej i często także moralnych rozterek w momencie obejmowania ich dóbr. Stanisław Drankiewicz, mieszkaniec wsi Przedmoście (który przybył tu jako mały chłopak z rodzeństwem i rodzicami), relacjonował:

Smutno o tym wspominać, ale Polak jak nie spoliczkował, to co innego wymyślił na Niemca. Pamiętam, bo miałem wówczas 12 lat i już wiele wiedziałem. W tym wieku to już trochę się rozumiało. Wśród Niemców, którzy tu pozostali, były głównie kobiety, ponadto dzieci i starsi mężczyźni. Młodych było bardzo mało, ponieważ wszyscy poszli na wojnę. Tacy dziadkowie byli jak ja teraz, 75 i 8o-latki oraz chłopaki co do szkoły jeszcze chodzili, po 10, 12 lat. Miałem z tymi młodymi Niemcami dobre układy. Kumplowałem się z nimi. Mieli ciekawe książki, nawet bardzo dużo książek. Co ciekawe, wręcz nie było żadnej różnicy między wszystkimi dziećmi z powodu tego, że jeden jest Niemcem, a drugi Polakiem² ${ }^{22}$.

20 B. Nitschke, Oswajanie „małych ojczyzn” na przykładzie odbudowy Starego Miasta Głogowie, s. 46.

21 K. Frąszczak, M. R. Górniak, M. Kuchnicki, Pamiętniki, relacje i wspomnienia osadników obecnej gminy Glogów (część 1), s. 61-62.

22 Tamże, s. 98. 
Z kolei inna mieszkanka wsi Przedmoście - Irena Kutzner - o relacjach z pozostającymi tu jeszcze Niemcami wspominała:

Gdy tu przyjechałam, to we wsi było jeszcze kilku Niemców. Ludzie pozajmowali mieszkania i czekali, aż Niemcy wyjadą. Stosunki między wszystkimi mieszkańcami zależały od Polaków. Niemiec siedział spokojniutko i bał się gdziekolwiek ruszyć, a Polak był dumny, bo panem się czuł ${ }^{23}$.

W pamiętnikach i relacjach osadników często spotykamy opisy dotyczące nieporadności przedstawicieli ówczesnej władzy, braku poczucia bezpieczeństwa wśród osadników, bezprawia - także w przypadku stacjonujących w terenie jednostek armii radzieckiej oraz wszechobecnego procederu szabrownictwa ${ }^{24}$. Adolf Batkowski (zdemobilizowany żołnierz 2. Armii Wojska Polskiego, mieszkający w Jerzmanowej) relacjonował o organizacji polskiej samoobrony przez osadników:

Ja i moi koledzy z jednostki staliśmy się pierwszymi osadnikami wojskowymi w Jerzmanowej. Tyle tylko można nadmienić, że były to ciężkie i niebezpieczne czasy. Bezpośrednio po wojnie nadal ginęli jeszcze ludzie. Jako pierwsi osadnicy musieliśmy utrzymywać porządek we wsi, mieliśmy nocne straże. Nowa władza była jeszcze słaba, milicji mało, a wielu rabusiów próbowało zabrać stąd co się tylko dało, tłumacząc że jeszcze wrócą Niemcy ${ }^{25}$.

Z kolei Florian Potrykowski (pełniący w 1945 r. funkcję sekretarza w Urzędzie Gminy Kotla) we wspomnieniach zasygnalizował praktykowanie przez rzekomych osadników procederu szabru:

We wsiach - jeszcze niezamieszkanych - pojawiali się szabrownicy, którzy plądrowali opuszczone mieszkania. Gdy pewnego razu jechałem rowerem przez niezamieszkałą wieś Serby, a potem wracałem, zauważyłem na drzwiach dość ładnego

23 Tamże, s. 127.

24 M. R. Górniak, Szabrownictwo, w: Encyklopedia „Białych Plam”, t. 20, Radom 2006, s. 265268; M. Zaremba, Wielka trwoga. Polska 1944-1947. Ludowa reakcja na kryzys, Kraków 2012, s. 275-280; P. Lewandowski, Gorzowski szaber. Stosunek polskich osadników do „poniemieckiego" miasta, "Nadwarciański Rocznik Historyczno-Archiwalny”, 21 (2014) s. 206-208; W. Maciuszczak, Służba niejedno ma imię. Z dziejów głogowskiej milicji i policji w latach 1945-2014, Głogów 2014, s. 27-33.

25 M. R. Górniak, Pamiętniki, relacje i wspomnienia osadników rejonu obecnej gminy Jerzmanowa (część 1). Okres pionierski 1945-1960, Jerzmanowa-Lublin 2012, s. 58. 
domu napis kredą, którego poprzednio nie było „Zajęto bez Polaka”. Postawiłem rower pod ścianą i wszedłem do środka. Był tam ten „bez Polak”, który nożem rozpruwał pluszowe obicie z kanapy. Zdenerwowałem się na niego i kazałem mu wynosić się jak najszybciej. Żeby zaszkodzić szabrownikom, zabroniliśmy osiedlania się bez zgody gminy. Sekretarz wypisał na maszynie kilka takich ogłoszeń, które zostały rozlepione na widocznych miejscach. Na ogłoszeniach była podana siedziba [Urzędu - przyp. M.R.G.] Gminy ${ }^{26}$.

Podobny, równie uderzający opis skutków szabru dostarcza relacja Witolda Pawłowskiego, mieszkańca wsi Jerzmanowa (pochodzącego z Kielc):

Jak się ożeniłem i tu zamieszkałem, to wszystko było już rozszabrowane. Tylko dziury w ścianach zostały, żadnego okna ani drzwi. Wszystko trzeba było gdzieś kombinować. Takie było życie. Nawet podłogi były powyrywane ${ }^{27}$.

Tadeusz Jaśko (z zawodu leśnik, mieszkający i pracujący na terenie gminy Grębocice) wspominał zaś o radzieckich żołnierzach, którzy zazwyczaj byli sprawcami najbardziej bezwzględnych grabieży:

[...] pewnego razu przyjechali żołnierze radzieccy-maruderzy, weszli na ogród i zaczęli zrywać owoce. Chwyciłem za karabin i wyszedłem (od słowa do słowa), a ponieważ było ich 6 zmusili mnie do ustąpienia. Co nie dali rady zabrać, to zniszczyli ${ }^{28}$.

\section{Rola Kościoła katolickiego w integrowaniu społeczeństwa Ziemi Głogowskiej}

Niezależnie od polityki władz państwowych warto podkreślić szczególną rolę, jaką bezpośrednio po wojnie odgrywał na tych ziemiach Kościół katolicki. Jak wiadomo, w dziejach Polski problematyka wyznaniowa zawsze związana była z tym, co narodowe. Stąd Kościół także miał wyjątkowe znaczenie w życiu narodu po drugiej wojnie światowej, a szczególnie na Ziemiach Odzyskanych, na które przybyli osadnicy i przesiedleńcy z różnych regionów kraju, a także Europy. Na Ziemiach Zachodnich

26 M. R. Górniak, Relacjei wspomnienia osadników rejonu gminy Kotla, Kotla-Lublin 2007, s. 125; J. Baraniecki, M. R. Górniak, Relacje i wspomnienia osadników rejonu gminy Kotla, s. 261.

27 M. R. Górniak, Pamiętniki, relacje i wspomnienia osadników rejonu obecnej gminy Jerzmanowa (częśś 2), s. 239.

28 Tenże, Pamiętniki i wspomnienia osadników rejonu gminy Grębocice (zeszyt 3), s. 101. 
(w tym także na Ziemi Głogowskiej) nastąpiło zderzenie odmiennych kultur i obyczajów. Dla przybyłych Kościół katolicki był czynnikiem gwarantującym poczucie stabilizacji (utrwalał tożsamość religijną i narodową) ${ }^{29}$.

Kościół od samego początku funkcjonowania na Ziemiach Odzyskanych miał wyraźne sprecyzowaną misję, aby z osiedlającej się tu ludności stworzyć społeczeństwo zintegrowane - najpierw ze sobą, następnie z ojczyzną, a później z Europą. Ludzie w pierwszej kolejności osiedlali się w miejscach, gdzie zastali księdza katolickiego i czynny kościół. Dla osadników wiara i świadomość obecności kapłana były giwarantem powodzenia na każdym odcinku ich życia w nowej rzeczywistości. Stając w obliczu różnych zagrożeń tożsamości narodowej, Kościół obejmował funkcję instytucji o wymiarze społecznym i pełnił niejednokrotnie funkcje zastępcze w sferze politycznej i społecznej (w sytuacji likwidacji lub ograniczenia świeckich instytucji życia narodowego). Pełniąc te funkcje rozwijał duszpasterstwo w różnorodnych formach, kierując je do wszystkich grup społecznych. Eksponował godność człowieka, organizował praktykowanie religijnego rytuału, który umacniał społeczeństwo w religii i patriotyzmie ${ }^{30}$.

Tekla Pendyk, mieszkanka Sobczyc (w gminie Kotla), wspominała:

Początkowo chodziliśmy do kościoła w Kotli. Później stary, zniszczony dom mieszkańcy przebudowali na kościółek, do którego przyjeżdżał odprawiać nabożeństwa ksiądz z Rapocina. Młodzież, w niedzielę po nabożeństwie, mogła spotykać się przy sali wiejskiej, gdzie śpiewali, grali na różnych instrumentach i tańczyli ${ }^{31}$.

29 Z. Lec, Kościót rzymskokatolicki na Dolnym Śląsku w powojennym pięćdziesięcioleciu, „Dolny Śląsk", 6 (2000) nr 8, s. 50; W. Irek, Integracja społeczno-narodowa Ziem Zachodnich, w: Integracja społeczno-narodowa Ziem Zachodnich. Wybrane problemy, red. M. Nieć, Wrocław 2006, s. 79-82; D. Śmierzchalski-Wachocz, Partia komunistyczna wobec Kościoła i przejawów wiary katolickiej $w$ swoich szeregach na przykładzie Środkowego Nadodrza w latach 1945-1989, Ząbki 2007, s. 90-91; B. Halicka, Polski Dziki Zachód, s. 268-279.

30 A. Barcik, Sól ziemi. Rola Kościoła katolickiego w powstaniu Polski Solidarnościowej, „Talent” (Duszpasterstwo Przedsiębiorców i Pracodawców), 5 (2005) s. 11-12; J. Pater, Polska administracja Kościoła rzymskokatolickiego na Dolnym Ślasku po II wojnie światowej, „Dolny Śląsk", 3 (1997) nr 4, s. 10-24; W. Czyżewski, Rola Kościoła katolickiego w integrowaniu Ziem Odzyskanych po roku 1945 (ze szczególnym uwzględnieniem administratury gorzowskiej), w: Jeszcze o Gorzowie, Gorzów Wielkopolski 2000, s. 72-82; K. Kowalczyk, W walce o „rząd dusz". Polityka władz państwowych wobec Kościoła katolickiego na. Pomorzu Zachodnim w latach 1945-1956, Szczecin 2003 (passim); D. A. Rymar, Gorzów Wielkopolski w latach 19451998. Przemiany społeczno-polityczne, Szczecin-Gorzów Wielkopolski 2005, s. 261-282.

31 J. Baraniecki, M. R. Górniak, Relacje i wspomnienia osadników rejonu gminy Kotla, s. 249. 
Natomiast Michał Serediuk - pochodzący z województwa tarnopolskiego - opisując powojenne tradycje związane z ceremoniałem weselnym (m.in. dotyczące ślubu kościelnego), podkreślał znaczenie zwyczajów religijnych wyniesionych ze swoich rodzinnych stron:

W organizacji i przebiegu wesela uwidocznity się zwyczaje przeniesione z rodzinnych stron. Było to prawdziwe widowisko dla całej wsi. Od rana orkiestra zaczynała grać u pana młodego witając, przybywających gości. Następnie pan młody szedł z orkiestrą do domu panny młodej. Przed nimi starosta ze starościną, tańcząc nieśli upieczony kołacz. U panny młodej według ustalonego ceremoniału miało miejsce błogosławieństwo, po którym wszyscy ruszali do kościoła. Po ślubie pan młody odprowadzał żonę wraz z jej gośćmi do jej rodzinnego domu, a swoich gości wiódł do domu, gdzie się wychował. Tak w 2 domach bawiono się do północy. Po północy młody „wykradał” żonę do swojego domu. W weselu brała udział prawie cała wieś. Na zabawę osobiście zapraszali państwo młodzi. Nie było mowy, by nie zaprosić sąsiadów na swoje wesele ${ }^{32}$.

W trudnych początkach powojennej egzystencji mieszkańców Ziemi Głogowskiej duży wpływ na przebieg procesów integracyjnych miało katolickie duchowieństwo (poza działalnością duszpasterską angażujące się w organizację polskiego życia społeczno-kulturalnego). Niejednokrotnie też obecność Kościoła wpływała na tempo zasiedlania poszczególnych miejscowości. W ten sposób religia stanowiła jeden z ważniejszych filarów procesów integracyjnych, a Kościół lokalny jednoczył ludność miejscową i napływową. Kościół katolicki zawsze stanowił dla mieszkańców autorytet duchowy i moralny, przez co z czasem na trwałe zintegrował ich z „małą ojczyzną"”3.

32 Tamże, s. 307-308.

33 T. Dzwonkowski, Administracja apostolska kamieńska, lubuska i pratatury pilskiej. Zarys dziejów 1945-1966, w: Księga pamiątkowa 50-lecia organizacji Kościoła katolickiego na Ziemi Lubuskiej, Pomorzu Zachodnim i Pótnocnym (1945-1995), Zielona Góra-Gorzów Wielkopolski 1998, s. 31; K. Jaworska, Rola Kościoła katolickiego w integrowaniu społeczeństwa dolnośląskiego w latach 1945-1951, „Zeszyty Naukowe Państwowej Wyższej Szkoły Zawodowej im. Witelona w Legnicy”, 1 (2013) nr 9, s. 7-8, 13-17. Autorka zwraca uwagę, iż: „Niemal każdą większą uroczystość poprzedzano mszą św., a zasiadający w pierwszych rzędach urzędnicy państwowi ostentacyjnie demonstrowali swój katolicyzm. Uczestnictwo duchowieństwa w uroczystościach państwowych było czynnikiem uwiarygodniającym władzę w oczach społeczeństwa". 


\section{Publikacje - ogólne omówienie}

Problematyka powojennego osadnictwa na Ziemi Głogowskiej doczekała się wielu cennych opracowann ${ }^{34}$. Najstarsze prace poruszające tematykę osadnictwa na obszarze Środkowego Nadodrza zostały zainicjowane w latach sześćdziesiątych przez Lubuskie Towarzystwo Kultury w ramach serii Mój dom nad Odra (1961 i 1965) i później były kontynuowane (1971, 1973 - książka w całości dotycząca Ziemi Głogowskiej, 1976, 1983, 1988) ${ }^{35}$. Jako pierwszy na szerszą skalę opracowania tej problematyki na gruncie ówczesnego powiatu głogowskiego podjął się Walenty Nawrocki (sekretarz Prezydium Powiatowej Rady Narodowej w Głogowie), który w latach 1967-1970 zebrał w trzech tomach zbiór wspomnień (maszynopis relacji 60 osób) ${ }^{36}$.

Ważnym zestawieniem materiałów, ukazującym wieloetniczne i wielokulturowe oblicze obszaru Legnicko-Głogowskiego Okręgu Miedziowego (pośrednio dotyczących także tego terenu), jest publikacja z 2013 r. Kto siedzi na miedzi(-y)?, wydana nakładem Legnickiego Centrum Kultury pod redakcją Jerzego Starzyńskiego. Podejmuje ona tematykę koegzystencji przybyłych na te ziemie po drugiej wojnie osadników, wśród których znaleźli się: Polacy, Niemcy, Grecy, Łemkowie, Macedończycy, Romowie i Żydzi. Wśród kilku wyodrębnionych rozdziałów opracowania znajdują się materiały dotyczące powojennych dziejów wsi Koźlice (gmina Gaworzyce) koło Głogowa, która stała się miejscem zamieszkania reemigrantów z Bukowiny ${ }^{37}$.

34 Szczegółowe opracowanie bibliograficzne dotyczące powojennych dziejów tego obszaru odnotowane zostały w publikacji Dolnośląskiej Biblioteki Pedagogicznej we Wrocławiu: L. Soszyńska, A. Dyrek, Publikacje poświęcone organizacji życia społecznego, naukowego, kulturalnego i gospodarczego na Ziemiach Odzyskanych. Zestawienie literatury z zasobów bibliotek i instytucji z powiatów Dolnego Ślaska, Wrocław 2016.

35 J. Koniusz, I. Solińska, Mój dom nad Odrą, Zielona Góra 1961; tenże, Mój dom nad Odra. Drugi tom wspomnień i pamiętników, Zielona Góra 1965; tenże, Mój dom nad Odrą. Pamiętniki i wspomnienia mieszkańców Ziemi Lubuskiej, Zielona Góra 1971; tenże, Mój dom nad Odra. Ze wspomnień głogowian, Zielona Góra 1973; Z. Dulczewski, Mój dom nad Odrą. Pamiętniki i wspomnienia, Zielona Góra 1976; A. Siatecki, Mój dom nad Odra. Pamiętniki i wspomnienia członków organizacji młodzieżowych Ziemi Lubuskiej, Zielona Góra 1983; J. Koniusz, Mój dom nad Odra. Ze wspomnień mieszkańców Ziemi Lubuskiej, Zielona Góra 1988.

36 W. Nawrocki, Wspomnienia osadników Ziemi Głogowskiej, t. 1-3, Głogów 1967-1970 (maszynopisy).

37 M. Pokrzyńska, Z Bukowiny do Gaworzyc, w: Kto siedzi na miedzi (-y)? red. J. Starzyński, Legnica 2013, s. 155-176. 
Wyjątkowo cennymi zbiorami wspomnień mieszkańców Legnicko-Głogowskiego Okręgu Miedziowego są prace: Franciszka Jakubczaka Ludzie i miedź. Pamiętniki $z$ legnicko-głogowskiego rejonu uprzemysławianego oraz dwutomowe dzieło Ocaleni z zatraty - relacje zebrane przez studentów Uczelni Zawodowej Zagłębia Miedziowego w Lubinie pod kierunkiem prof. Stanisława Beresia ${ }^{38}$. Na szczególną uwagę zasługują dzieła autorów pamiętników (także uprawiających twórczość poetycką), którzy poza obszarem głogowskim i polkowickim podjęli także szerzej problematykę Kresów: Janina Zimirska (gmina Grębocice), Edward Gross (gmina Jerzmanowa) oraz Zbigniew Rajche (gmina Polkowice) ${ }^{39}$. Innymi godnymi odnotowania publikacjami są prace zbiorowe pod redakcją: Krzysztofa Jelenia, Leszka Rydza, Marka Sadowskiego, Jakuba Tyszkiewicza czy Alfreda Röslera ${ }^{40}$ oraz opracowania Barbary Floty i Krzysztofa Zawickiego ${ }^{41}$. Warto również podkreślić, iż z inicjatywy czterech podgłogowskich gmin wiejskich ukazały się serie wydawnicze podejmujące szczegółowo problematykę osadnictwa na tym obszarze: Grębocice (2006, 2008, 2011, 2013), Głogów (2015), Jerzmanowa $(2012,2014)$ oraz Kotla $(2007,2012,2015)$. Z najnowszych publikacji wydanych przez Towarzystwo Ziemi Głogowskiej należy odnotować pracę wspomnieniową Historia jednego kwartału. Wspomnienia mieszkańców stoczniowca opracowaną przez Dariusza Jarosza i Marcina Kuchnickiego ${ }^{42}$.

38 F. Jakubczak, Ludzie i miedź. Pamiętniki z legnicko-głogowskiego rejonu uprzemysławianego, Warszawa 1974; S. Bereś, Pamięć ocalonych, w: Kresowe dziedzictwo. Studia nad językiem, historia i kultura, red. A. Budzyńska-Kamieniecka, M. Misiak, J. Kamieniecki, Wrocław 2012, s. 277-293; Ocaleni z zatraty, t. 2: Relacje mieszkańców ziemi lubińsko-legnickiej, red. S. Bereś, Wrocław 2014.

39 E. Gross, Kresowe dzieje podolskich wsi: Wołochy, Ponikwa i Hucisko Brodzkie (1938-1944), Wrocław 2004; tenże, Tragedia Podola, Głogów 2007; J.Zimirska, $W$ drodze do domu. Ze wspomnień, Warszawa 2012, s. 155-176; Z. Rajche, Na nowej ziemi: wspomnienia przesiedleńca na Ziemie Zachodnie (1946-1948), Zielona Góra 2016.

40 Moja mała ojczyzna - gmina Pęcław, red. M. Sadowski i in., Białołęka-Wietszyce 2005; Głogów - moje miejsce na Ziemi, red. K. Jeleń, Głogów 2010; Kucharska księga wspomnień gminy Głogów, red. L. Rydz, Głogów 2010; Polkowice w mojej pamięci. Materiały Międzynarodowego Konkursu na pracę wspomnieniowo-historyczna, red. J. Tyszkiewicz, Polkowice 2011; Z Kresów do ... Sławy. Wspomnienia Kresowian, red. A. Rösler, Sława 2016.

41 Z. Dulczewski, Drugie pokolenie. Wspomnienia mieszkańców zachodnich i pótnocnych ziem Polski, Poznań 1978; B. Flota, Miedź i medycyna, Wrocław-Lubin 2010; K. Zawicki, Ocalić od zapomnienia, Głogów 2015.

42 D. Jarosz, M. Kuchnicki, Historia jednego kwartału. Wspomnienia mieszkańców „stoczniowca”, Głogów 2015. 


\section{Podsumowanie}

Powstawanie nowych więzi społecznych na Ziemiach Odzyskanych dokonywało się w trzech etapach. Na początku, w okresie zasiedlania, dochodziło do separatyzmu, wynikającego z różnic pochodzenia regionalnego osadników (m.in. różne tradycje i wizje funkcjonowania zbiorowości). Drugi etap integracji i adaptacji (przebiegający do 1958 r.) charakteryzował się stopniowym zanikiem różnic kulturowych, przenikaniem różnorodnych kultur regionalnych oraz pojawieniem się poczucia przywiązania do tych ziem. Kolejny etap (po 1958 r.) zakończył pojawianie się wątpliwości o tymczasowości przynależności tych ziem do Polski i doprowadził do upodobnienia się tego obszaru do reszty kraju ${ }^{43}$.

Los zetknął przybyłych na te ziemie po drugiej wojnie osadników, wśród których byli ludzie z różnych regionów Polski i Europy (m.in.: Polacy, Niemcy, Grecy, Łemkowie, Macedończycy, Romowie i Żydzi). Znaleźli się oni w sytuacji ekstremalnie niekorzystnej dla nawiązania życzliwego współżycia. Ale właśnie w tych szczególnych warunkach ta istna mozaika ludnościowa przeżyła przemianę. Od nieufności i strachu, poprzez wzajemną obserwację, współpracę i przezwyciężanie wspólnych trudności, do przyjaźni. Małe gesty dobrej woli, współczucia i lojalności wytworzyły pomost wzajemnego porozumienia. Od powojennego chaosu przebyli oni drogę nieodzownego uporządkowania życia społecznego i doszli do integracji swoistej mozaiki ludnościowej ${ }^{44}$.

W swoich powojennych refleksjach Jan Łodej (pedagog, 1954-1955 nauczyciel w Szkole Podstawowej w Kwielicach w gminie Grębocice) odnotował:

W mojej świadomości tkwiła podstawowa prawda. Dla zjednoczenia tych ludzi z różnych stron trzeba było robić wszystko, aby polubili ten nowy dom, obyczaje, kulturę sąsiadów i dobre strony przyswajali sobie na wspólny pożytek. Z perspektywy czasu można stwierdzić, że zadanie w sporej części zostało wykonane ${ }^{45}$.

43 W. Irek, Integracja społeczno-narodowa Ziem Zachodnich, s. 74-75; W. Misiak, Kierunki i charakter przemian społecznych na Dolnym Śląsku w 50-leciu, „Dolny Śląsk”, 2 (1996) nr 2, s. 247249; F. Nowak-Małolepsza, Mniejszości narodowe na Ziemi Lubuskiej po II wojnie światowej, Zielona Góra 2011, s. 5-11; M. R. Górniak, Integracyjna rola Kościoła katolickiego w powojennych dziejach społeczeństwa Głogowa (ze szczególnym uwzględnieniem okresu pionierskiego 1945-1960), w: Głogów. Historia i perspektywy rozwoju, red. J. Hermaszewski, E. Czaińska, B. Kohlman, Głogów 2010, s. 88-89.

44 J. Swastek, Rządcy archidiecezji wrocławskiej w latach 1945-1995, Wrocław 1998, s. 10; B. Techmańska, Jestem stąd, więc ... - poczucie tożsamości mieszkańców ziemi lubińskiej i polkowickiej, „Rocznik Lubuski”, 35 (2009) cz. 1, s. 235-243.

45 M. R. Górniak, Pamiętniki i wspomnienia osadników rejonu gminy Grębocice (zeszyt 3), s. 154. 
Każda z omawianych w niniejszym szkicu relacji jest unikalna i ma wyjątkowe walory, zawierając m.in. wiele cennych informacji ukazujących różne drogi, którymi mieszkańcy tego regionu zmierzali do swojej nowej „małej ojczyzny”. Ponadto ich wspomnienia stanowią nieocenione źródło opisu życia codziennego, postaw mentalnych, procesu zakorzeniania się Polaków na tych ziemiach oraz pozwalają odtworzyć lokalną specyfikę i klimat społeczny lat powojennych. W łącznym zestawieniu zaprezentowane wspomnienia powojenne dają wieloaspektowy obraz powojennej rzeczywistości. Z wyżej zasyg̉nalizowanych powodów zgromadzone w pracy dane wnoszą więc ważną cząstkę do dorobku powojennej polskiej historiografii Ziemi Głogowskiej, a szerzej Ziem Zachodnich.

Streszczenie: Przedmiotem niniejszego artykułu jest prezentacja zbioru pamiętników, relacji i wspomnień wydanych w latach 2006-2015 w ramach serii publikacji ukazujących powojenne dzieje Dolnego Śląska, a szczególnie Ziemi Głogowskiej. Punktem wyjścia do podjętej charakterystyki życia ludzi, którzy zasiedlili Ziemie Odzyskane były wydarzenia 1945 r. Jednocześnie zestawiając losy tych osób, nie pomijano ich przeżyć z okresu II wojny światowej.

Różne były losy i przeżycia Polaków, którzy po 1945 r. zasiedlili Ziemie Odzyskane, w tym także Ziemię Głogowską. W gronie osadników znaleźli się ekspatrianci, ludzie wypędzeni z Ziem Wschodnich, deportowani podczas wojny przez władze radzieckie, oraz przesiedleńcy z centralnej Polski, o różnym pochodzeniu społecznym i rozmaitych profesjach.

Każda z omawianych w ramach serii relacji jest unikalna i ma wyjątkowe walory, zawierając m.in. wiele cennych informacji ukazujących różne drogi, którymi mieszkańcy tego regionu zmierzali do swojej nowej „małej ojczyzny”. Ponadto wspomnienia stanowią nieocenione źródło opisu życia codziennego, postaw mentalnych, procesu zakorzeniania się Polaków na tych ziemiach oraz pozwalają odtworzyć lokalną specyfikę i klimat społeczny lat powojennych.

W latach 1945-1950 na Ziemi Głogowskiej nie było ludności jednolitej pod względem etniczno-kulturowym, a proces integracyjny przebiegał wolno. Tworzenie nowych więzi społecznych dokonywało się tu w trzech etapach. Na początku w okresie zasiedlania Ziem Odzyskanych dochodziło do separatyzmu, wynikającego z różnic pochodzenia regionalnego osadników (m.in. różne tradycje i wizje funkcjonowania zbiorowości). Drugi etap integracji i adaptacji (przebiegający do 1958 r.) charakteryzował się stopniowym zanikiem różnic kulturowych, przenikaniem różnorodnych kultur regionalnych oraz pojawieniem się poczucia przywiązania do tych ziem. Kolejny, trzeci etap (nastąpił po 1958 r.) zakończył pojawianie się wątpliwości o tymczasowości przynależności tych ziem do Polski i doprowadził do upodobnienia się tego obszaru do reszty kraju.

Wspomnienia powojenne dają wieloaspektowy obraz powojennej rzeczywistości, wnoszą więc ważną cząstkę do dorobku powojennej polskiej historiografii Ziemi Głogowskiej, a szerzej Ziem Zachodnich.

Słowa kluczowe:Ziemia Głogowska, Ziemie Odzyskane, pamiętniki, relacje, wspomnienia, przesiedlenia 


\section{Bibliografia}

Archiwum Akt Nowych, Zarząd Centralny Państwowego Urzędu Repatriacyjnego w Łodzi. Baraniecki J., M. R. Górniak, Relacje i wspomnienia osadników rejonu gminy Kotla, Kotla-Lublin 2012. Barcik A., Sól ziemi. Rola Kościoła katolickiego w powstaniu Polski Solidarnościowej, „Talent” (Duszpasterstwo Przedsiębiorców i Pracodawców), 5 (2005) s. 11-12.

Bereś S., Pamięć ocalonych, w: Kresowe dziedzictwo. Studia nad językiem, historią i kultura, red. A. Budzyńska-Kamieniecka, M. Misiak, J. Kamieniecki, Wrocław 2012, s. 277-293.

Chutkowski J., Głogów w Xx wieku. Zarys monograficzny, Głogów 2004.

Czaińska E. M., Charakterystyka uwarunkowań kształtowania się osadnictwa oraz rozwoju miasta Głogowa pod wpływem powstania Huty Miedzi , w: Głogów historia i perspektywy rozwoju, red. J. Hermaszewski, E. Czaińska, B. Kohlman, Głogów 2010, s. 85-93.

Czaińska E., Świadomość tożsamości lokalnej a jej wpływ na rozwój gospodarczy miasta Głogowa, w: Głogów tu i teraz, red. E. Czaińska, J. Hermaszewski, B. Kohlman, Głogów 2011.

Czyżewski W., Rola Kościoła katolickiego w integrowaniu Ziem Odzyskanych po roku 1945 (ze szczególnym uwzględnieniem administratury gorzowskiej), w: Jeszcze o Gorzowie, Gorzów Wielkopolski 2000.

Dulczewski Z., Drugie pokolenie. Wspomnienia mieszkańców zachodnich i pótnocnych ziem Polski, Poznań 1978.

Dulczewski Z., Mój dom nad Odrą. Pamiętniki i wspomnienia, Zielona Góra 1976, mps.

Dzwonkowski T., Administracja apostolska kamieńska, lubuska i prałatury pilskiej. Zarys dziejów 1945-1966, w: Księga pamiątkowa 50-lecia organizacji Kościoła katolickiego na Ziemi Lubuskiej, Pomorzu Zachodnim i Pótnocnym (1945-1995), Zielona Góra-Gorzów Wielkopolski 1998, s. 23-54.

Flota B., Miedź i medycyna, Wrocław-Lubin 2010.

Frąszczak K., M. R. Górniak, M. Kuchnicki, Pamiętniki, relacje i wspomnienia osadników obecnej gminy Głogów (część 1). Przedmoście, Głogów-Lublin 2015.

Głogów - moje miejsce na Ziemi, red. K. Jeleń, Głogów 2010.

Górniak M. R., 70 lat Ochotniczej Straży Pożarnej w Jaczowie. Zarys dziejów 1946-2016, Jerzmanowa - Lublin 2016, s. 25-38.

Górniak M. R., Integracyjna rola Kościoła katolickiego w powojennych dziejach społeczeństwa Głogowa (ze szczególnym uwzględnieniem okresu pionierskiego 1945-1960), w: Głogów. Historia i perspektywy rozwoju, red. J. Hermaszewski, E. Czaińska, B. Kohlman, Głogów 2010, s. 83-93.

Górniak M. R., Pamiętniki i wspomnienia osadników rejonu gminy Grębocice (zeszyt 2). Powojenne relacje nauczycieli i absolwentów szkół z terenu gminy, Grębocice-Lublin 2008.

Górniak M. R., Pamiętniki i wspomnienia osadników rejonu gminy Grębocice (zeszyt 3). Pionierzy i ich następcy, Grębocice-Lublin 2011.

Górniak M. R., Pamiętniki, relacje i wspomnienia osadników rejonu obecnej gminy Jerzmanowa (część 2). Robotnicy przymusowi, pionierzy polskiego osadnictwa i ich następcy, JerzmanowaLublin 2014. 
Górniak M. R., Pamiętniki, relacje i wspomnienia osadników rejonu obecnej gminy Jerzmanowa (część 1). Okres pionierski 1945-1960, Jerzmanowa-Lublin 2012.

Górniak M. R., Relacje i wspomnienia osadników rejonu gminy Kotla, Kotla-Lublin 2007.

Górniak M. R., Społeczno-religijna rola zakonów i stowarzyszeń katolickich w powojennych dziejach Ziemi Głogowskiej (ze szczególnym uwzględnieniem okresu pionierskiego 1945-1960), w: Głogów tu i teraz, red. E. Czaińska, J. Hermaszewski, B. Kohlman, Głogów 2011, s. 95-115.

Górniak M. R., Szabrownictwo, w: Encyklopedia „Białych Plam”, t. 20, Radom 2006, s. 265-268.

Górniak M. R., Ziemie Odzyskane, w: Encyklopedia „Białych Plam”, t. 18, red. A. Winiarczyk, Radom 2006, s. 252-255.

Gross E., Kresowe dzieje podolskich wsi: Wołochy, Ponikwa i Hucisko Brodzkie (1938-1944), Wrocław 2004.

Gross E., Tragedia Podola, Głogów 2007.

Habranowicz J., Wielokulturowość Ziem Zachodnich po II wojnie światowej w pamiętnikach osadników, „Dolny Śląsk”, 14 (2008) nr 13, s. 30-42.

Halicka B., Polski Dziki Zachód. Przymusowe migracje i kulturowe oswajanie Nadodrza 19451948, Kraków 2015.

Hanich A., Powojenna „repatriacja” Polaków z Kresów Wschodnich na Śląsk Opolski, w: Wokół ludzi i zdarzeń. Przesiedleńcy z dawnych Kresów Rzeczypospolitej w strukturze demograficznej i społecznej Śląska Opolskiego w sześćdziesięcioleciu 1945-2005, red. R. Ramziński, T. Sołdra-Gwiżdż, Opole 2011, s. 11-25.

Hejger M., Przekształcenia narodowościowe na Ziemiach Zachodnich i Północnych Polski w latach 1945-1959, Słupsk 2008.

Irek W., Integracja społeczno-narodowa Ziem Zachodnich, w: Integracja społeczno-narodowa Ziem Zachodnich. Wybrane problemy, red. M. Nieć, Wrocław 2006, s. 83-95.

Jacher W., Problemy adaptacji społeczno-kulturowej ludności polskiej na Ziemiach Zachodnich i Północnych po 1945 roku, w: Polskie Ziemie Zachodnie. Studia socjologiczne, red. A. Michalak, A. Sakson, Ż. Stasieniuk, Poznań 2011, s. 67-78.

Jakubczak F., Ludzie i miedź. Pamiętniki z legnicko-głogowskiego rejonu uprzemysławianego, Warszawa 1974.

Jarosz D., M. Kuchnicki, Historia jednego kwartału. Wspomnienia mieszkańców „stoczniowca”, Głogów 2015.

Jasiński J., Kwestia pojęcia Ziemie Odzyskane, w: Ziemie Odzyskane / Ziemie Zachodnie i Północne 1945-2005. 6o lat w granicach państwa polskiego, red. A. Sakson, Poznań 2006, s. 27-44.

Jaworska K., Rola Kościoła katolickiego w integrowaniu społeczeństwa dolnoślaskiego w latach 1945-1951, „Zeszyty Naukowe Państwowej Wyższej Szkoły Zawodowej im. Witelona w Legnicy", 1 (2013) nr 9, s. 7-8, 13-17.

Kominek B., W służbie „Ziem Zachodnich”, Wrocław 1977.

Koniusz J., Mój dom nad Odrą. Drugi tom wspomnień i pamiętników, Zielona Góra 1965.

Koniusz J., Mój dom nad Odra. Pamiętniki i wspomnienia mieszkańców Ziemi Lubuskiej, Zielona Góra 1971. 
Koniusz J., Mój dom nad Odra. Ze wspomnień mieszkańców Ziemi Lubuskiej, Zielona Góra 1988, mps.

Koniusz J., Mój dom nad Odrą. Ze wspomnień głogowian, Zielona Góra 1973, mps.

Koniusz J., I. Solińska, Mój dom nad Odrą, Zielona Góra 1961.

Konopnicka M., J. Helwig, Wstęp do dziennika Paula Pätzolda, w: Glogau 1945. Upadek twierdzy, Wrocław-Głogów 2015, s. 107-112.

Kowalczyk K., W walce o „rząd dusz”. Polityka władz państwowych wobec Kościoła katolickiego na. Pomorzu Zachodnim w latach 1945-1956, Szczecin 2003.

Kucharska księga wspomnień gminy Głogów, red. L. Rydz, Głogów 2010.

Kulak T., Wrocław - polskie miasto o niemieckiej przeszłości, w: Poznań - Szczecin - Wrocław. Trzy uniwersytety, trzy miasta, trzy regiony, red. W. Łazuga, S. Paczos, Poznań 2010, s. 83-98.

Kwaśniewski K., Adaptacja i integracja kulturowa ludności Śląska po II wojnie światowej, Wrocław 1968.

Lec Z., Kościół rzymskokatolicki na Dolnym Śląsku w powojennym pięćdziesięcioleciu, „Dolny Śląsk", 6 (2000) nr 8, s. 50-56.

Lewandowski P., Gorzowski szaber. Stosunek polskich osadników do "poniemieckiego" miasta, „Nadwarciański Rocznik Historyczno-Archiwalny”, 21 (2014) s. 206-208.

Lewandowski P., Wschód i zachód przemieszczone oraz odtworzone. Powstanie postmigracyjnego społeczeństwa polskich Ziem Zachodnich, „Kultura i Społeczeństwo”, 2013, nr 3, s. 203-215.

Maciuszczak W., Służba niejedno ma imię. Z dziejów głogowskiej milicji i policji w latach 19452014, Głogów 2014.

Maciuszczak W., Twierdza Głogów. Garnizon i ludzie. 1630-2009, Głogów 2009.

Matwijowski K., Głogów. Zarys monografii miasta, Wrocław 1994.

Mazur Z., O adaptacji niemieckiego dziedzictwa kulturowego na Ziemiach Zachodnich i Pótnocnych, Poznań 2001.

Misiak W., Kierunki i charakter przemian społecznych na Dolnym Śląsku w 50-leciu, „Dolny Śląsk", 2 (1996) nr 2.

Moja mała ojczyzna - gmina Pęcław, red. M. Sadowski i in., Białołęka - Wietszyce 2005.

Mordawski H., Ziemie Odzyskane 1945-1956, Brzezia Łąka 2015.

Nawrocki W., Wspomnienia osadników Ziemi Głogowskiej, t. 1-3, Głogów 1967-1970, mps.

Nitschke B., Oswajanie „małych ojczyzn” na przykładzie odbudowy Starego Miasta Głogowie, w: Głogów. Historia i perspektywy rozwoju, red. J. Hermaszewski, E. Czaińska, B. Kohlman, Głogów 2010, s. 45-56.

Nowak-Małolepsza F., Mniejszości narodowe na Ziemi Lubuskiej po II wojnie światowej, Zielona Góra 2011, s. 5-11.

Nowosielska-Sobel J., „Na barkach nieśli krajobraz” - z problemów oswajania przez osadników przestrzeni na przykładzie powiatu jeleniogórskiego drugiej połowy lat 40., w: Trudne dziedzictwo. Tradycje dawnych i obecnych mieszkańców Dolnego Ślaska, red. J. Nowosielska-Sobel, G. Strauchold, Wrocław 2006, s. 127-142.

Ocaleni z zatraty, t. 2: Relacje mieszkańców ziemi lubińsko-legnickiej, red. S. Bereś, Wrocław 2014. 
Pater J., Polska administracja Kościoła rzymskokatolickiego na Dolnym Śląsku po II wojnie światowej, „Dolny Śląsk”, 3 (1997) nr 4, s. 10-24.

Pokrzyńska M., Z Bukowiny do Gaworzyc, w: Kto siedzi na miedzi (-y)?, red. J. Starzyński, Legnica 2013, s. 155-176.

Polkowice w mojej pamięci. Materiały Międzynarodowego Konkursu na pracę wspomnieniowo-historyczna, red. J. Tyszkiewicz, Polkowice 2011.

Rajche Z., Na nowej ziemi: wspomnienia przesiedleńca na Ziemie Zachodnie (1946-1948), Zielona Góra 2016.

Rykiel Z., Kolonizacja a tożsamość społeczna na Ziemiach Zachodnich - przykład Zielonej Góry, w: Polskie Ziemie Zachodnie. Studia socjologiczne, red. A. Michalak, A. Sakson, Ż. Stasieniuk, Poznań 2011, s. 101-118.

Rymar D.A., Gorzów Wielkopolski w latach 1945-1998. Przemiany społeczno-polityczne, Szczecin-Gorzów Wielkopolski 2005.

Sakson A., Procesy integracji i dezintegracji społecznej na Ziemiach Zachodnich i Północnych Polski po 1945 roku, w: Pomorze - trudna ojczyzna. Kształtowanie się nowej tożsamości 19451995, red. A. Sakson, Poznań 1996, s. 131-154.

Siatecki A., Mój dom nad Odrą. Pamiętniki i wspomnienia członków organizacji młodzieżowych Ziemi Lubuskiej, Zielona Góra 1983, mps.

Soszyńska L., A. Dyrek, Publikacje poświęcone organizacji życia społecznego, naukowego, kulturalnego i gospodarczego na Ziemiach Odzyskanych. Zestawienie literatury z zasobów bibliotek i instytucji z powiatów Dolnego Śląska, Wrocław 2016.

Suleja W., Trudny proces zakorzeniania. Kresowiacy na Dolnym Śląsku, w: Kresowe dziedzictwo. Studia nad językiem, historią i kulturą, red. A. Budzyńska-Kamieniecka, M. Misiak, J. Kamieniecki, Wrocław 2012, s. 269-275.

Swastek J., Rządcy archidiecezji wrocławskiej w latach 1945-1995, Wrocław 1998.

Szulc P., Pozyskane ziemie odzyskane, „Pamięć i Przeszłość”, 15(2015) nr 2(28), s. 6-14.

Śmierzchalski-Wachocz D., Partia komunistyczna wobec Kościoła i przejawów wiary katolickiej w swoich szeregach na przykładzie Środkowego Nadodrza w latach 1945-1989, Ząbki 2007.

Techmańska B., Jestem stąd, więc ... - poczucie tożsamości mieszkańców ziemi lubińskiej i polkowickiej, „Rocznik Lubuski”, 35 (2009) cz. 1, s. 235-243.

Wojtowicz H., M. Garbera, Rozalia Berhel, w: Ocaleni z zatraty II. Relacje mieszkańców ziemi lubińsko-legnickiej, red. A. Bereś, Wrocław 2014, s. 87-89.

Z Kresów do ... Sławy. Wspomnienia Kresowian, red. A. Rösler, Sława 2016.

Zaremba M., Wielka trwoga. Polska 1944-1947. Ludowa reakcja na kryzys, Kraków 2012.

Zawicki K., Ocalić od zapomnienia, Głogów 2015.

Zimirska J., W drodze do domu. Ze wspomnień, Warszawa 2012.

Żurek R., Kościół rzymskokatolicki w Polsce wobec Ziem Zachodnich i Północnych 1945-1948, Szczecin-Warszawa-Wrocław 2015, s. 470-509. 